\title{
Frequency of Werner helicase 1367 polymorphism and age-related morbidity in an elderly Brazilian population
}

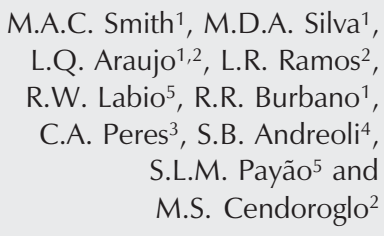

M.A.C. Smith ${ }^{1}$, M.D.A. Silva ${ }^{1}$, L.Q. Araujo ${ }^{1,2}$, L.R. Ramos², R.W. Labio ${ }^{5}$, R.R. Burbano ${ }^{1}$, C.A. Peres ${ }^{3}$, S.B. Andreoli ${ }^{4}$, S.L.M. Payão ${ }^{5}$ and M.S. Cendoroglo ${ }^{2}$

\author{
1Departamento de Morfologia, ${ }^{2}$ Departamento de Clínica Médica, \\ ${ }^{3}$ Departamento de Medicina Preventiva, ${ }^{4}$ Departamento de Psiquiatria, \\ Escola Paulista de Medicina, Universidade Federal de São Paulo, São Paulo, \\ SP, Brasil \\ ${ }^{5}$ Disciplina de Genética e Biologia Molecular, Hemocentro, \\ Faculdade de Medicina de Marília, Marília, SP, Brasil
}

\begin{abstract}
\section{Correspondence}

M.A.C. Smith

Disciplina de Genética

Departamento de Morfologia

EPM, UNIFESP

Rua Botucatu, 740

04023-900 São Paulo, SP

Brasil

Fax: +55-11-5576-4260

E-mail: macsmith.morf@epm.br

Research supported by FAPESP, CAPES and CNPq.

.....................

Received March 22, 2004 Accepted April 26, 2005

Werner syndrome (WS) is a premature aging disease caused by a mutation in the WRN gene. The gene was identified in 1996 and its product acts as a DNA helicase and exonuclease. Some specific WRN polymorphic variants were associated with increased risk for cardiovascular diseases. The identification of genetic polymorphisms as risk factors for complex diseases affecting older people can improve their prevention, diagnosis and prognosis. We investigated WRN codon 1367 polymorphism in 383 residents in a district of the city of São Paulo, who were enrolled in an Elderly Brazilian Longitudinal Study. Their mean age was $79.70 \pm 5.32$ years, ranging from 67 to 97 . This population was composed of 262 females $(68.4 \%)$ and 121 males $(31.6 \%)$ of European $(89.2 \%)$, Japanese $(3.3 \%)$, Middle Eastern $(1.81 \%)$, and mixed and/or other origins $(5.7 \%)$. There are no studies concerning this polymorphism in Brazilian population. These subjects were evaluated clinically every two years. The major health problems and morbidities affecting this cohort were cardiovascular diseases $(21.7 \%)$, hypertension $(83.7 \%)$, diabetes $(63.3 \%)$, obesity (41.23\%), dementia (8.0\%), depression (20.0\%), and neoplasia (10.8\%). Their prevalence is similar to some urban elderly Brazilian samples. DNA was isolated from blood cells, amplified by PCR and digested with PmaCI. Allele frequencies were 0.788 for the cysteine and 0.211 for the arginine. Genotype distributions were within that expected for the Hardy-Weinberg equilibrium. Female gender was associated with hypertension and obesity. Logistic regression analysis did not detect significant association between the polymorphism and morbidity. These findings confirm those from Europeans and differ from Japanese population.
\end{abstract}

Key words

- WRN: codon 1367

polymorphism

- Age-related morbidities

- Elderly cohort study

........ 


\section{Introduction}

Werner syndrome (WS) or Adult Progeria is a rare autosomal recessive disorder characterized as a segmental progeroid syndrome (1). WS patients develop the appearance of advanced aging in middle-age, including age-related disorders usually seen in normal elderly subjects, such as atherosclerosis, diabetes mellitus, osteoporosis, and neoplasias. The major cause of death is myocardial infarction (1-5).

Positional cloning identified $W R N$ as the gene responsible for WS (6). The mutant gene is a member of the RECQ family of helicases together with catalytic and exonuclease activities, and its product probably functions in basic types of DNA transactions, such as replication, repair, recombination, and transcriptional and chromosomal segregation. Recent studies also suggest that RecQ helicases act as genome caretakers (7$10)$.

Specific $W R N$ polymorphisms have been studied to understand the impact of molecular variants on longevity in WS as well as other age-related disorders and can yield new insights to its biological and pathological role $(3,4,8,11)$. The identification of genetic polymorphisms as risk factors for complex diseases in elderly people can be relevant for their prevention, diagnosis and prognosis.

An initial study of WRN:1367 polymorphism carried out in a Japanese population showed that the homozygosity of cysteine predicted a three-fold higher incidence of myocardial infarction than in normal control patients (11), a finding that was subsequently confirmed by Morita et al. (12) in the same population. The relatively homogeneous Finnish population shows high rates of coronary atherosclerosis and the putatively protective effect of the 1367 arginine $(\mathrm{R})$ allele has been investigated in centenarians in comparison with newborns. However, no significant differences were observed between the two age groups (3).

Population studies of WRN 1074 Leu/ Phe and 1367 Cys/Arg polymorphisms in Finnish, Mexican and North American subjects revealed only a tendency for the 1074 Phe allele to be associated with coronary stenosis and that the 1367 Arg/Arg (RR) genotype tended to protect against coronary artery occlusion, although without statistical significance (4).

The involvement of $W R N: 1367$ polymorphism in age-associated disorders was observed by Ogata et al. (13), who reported lower bone density of the lumbar spine in postmenopausal $\mathrm{C}$ allele-carrying Japanese women. Long-term hemodialysis patients also showed an association with this polymorphism (14).

In the present study, we investigated allele frequencies and the association of $W R N: 1367$ polymorphism with major morbidities that affect the elderly in a São Paulo, Brazil, community. These people participate in a longitudinal study of Brazilian elderly individuals initiated in 1991. This is the first longitudinal study in Brazil analyzing $W R N$ : 1367 polymorphism in elderly people.

\section{Material and Methods}

\section{Population}

The study population consisted of 383 participants from the Elderly Longitudinal Study (15). This study began in 1991 and originally involved 1667 people older than 66 years living in a district of São Paulo, Brazil. The mean age of this population was $79.80 \pm 5.32$ years (range: $66-97$ ). Subjects were evaluated clinically every two years and a subsample of 383 in wave 4 (20002001) was invited to participate in our study. This population was composed of individuals of European origin (89.2\%), Japanese origin (3.3\%), Middle Eastern origin (1.81\%), and mixed and/or other origin (5.70\%).

Clinical inquiries were performed to ob- 
tain information about previous diseases, current medication use, lifestyle, and anthropometric and blood pressure measurements. We informed participants about the study protocol. Physicians performed the physical exam and blood was collected for laboratory procedures.

Positivity for cardiovascular disease was considered to be present when individuals self-reported previous myocardial infarction, coronary heart disease, transitory ischemic attack or cerebrovascular disease, and were taking specific medication prescribed by physicians.

Those currently using anti-hypertensive drugs or those with systolic blood pressure above 140 or diastolic blood pressure above $95 \mathrm{mmHg}$ were considered to be positive for hypertension $(16,17)$. Those currently taking insulin or oral medication and those with fasting glucose equal to or above $126 \mathrm{mg} / \mathrm{dl}$ were considered to be positive for type II diabetes (18).

Positivity for neoplasia was considered when individuals self-reported a previous diagnosis with confirmation in their medical record, which presented the results of histological examination among others.

Subjects with a body mass index above $27 \mathrm{~kg} / \mathrm{m}^{2}(19,20)$ specifically for 65 years of age and older were considered to be positive for obesity.

Cognitive function was evaluated by the Mini-Mental State Examination (MMSE) screening instrument (21) validated for the Brazilian population (22). An MMSE score lower than 24 (out of 30) has $80-90 \%$ sensitivity and $80 \%$ specificity for discriminating individuals with low cognition level (roughly classified as dementia) from normal subjects $(22,23)$. Depression was characterized by a score above 5 in a validated Brazilian version of the Older American's Resources and Services questionnaire (24).

Although some studies have shown that self-reported past history and medical records are usually concordant for selected medical conditions in the elderly (25), past histories were only accepted when there was also evidence in physical examinations, ECG, CT-scan, or physician reports.

The Research Ethics Committee of UNIFESP approved this study and all participants gave written informed consent according to the Helsinki Declaration.

\section{DNA extraction}

Whole blood was collected into tubes containing 0.1\% EDTA and genomic DNA was isolated according to Lahiri and Nurnberger Jr. (26).

\section{Genotyping}

$W R N: 1367$ polymorphism was analyzed using the method of Ye et al. (11). A 193-bp sequence containing the polymorphic site was amplified by the polymerase chain reaction (PCR) using the following primers: sense: 5-'GCCTAATCAGAATGTTAGTT3', antisense: 5'-TCAGTATTGATGCCTAC CTC-3'.

Each PCR preparation contained $50 \mathrm{ng}$ genomic DNA in 10\% PCR buffer, $2 \mathrm{mM}$ $\mathrm{MgCl}, 0.2 \mathrm{mM}$ dNTPs, $2.5 \mathrm{U}$ Taq polymerase, and $10 \mathrm{mM}$ each primer. The mixture was heated for $5 \mathrm{~min}$ at $95^{\circ} \mathrm{C}$ and underwent 35 amplification cycles: annealing $\left(55^{\circ} \mathrm{C}\right.$ for $30 \mathrm{~s})$, extension $\left(72^{\circ} \mathrm{C}\right.$ for $\left.45 \mathrm{~s}\right)$ and denaturation $\left(94^{\circ} \mathrm{C}\right.$ for $\left.45 \mathrm{~s}\right)$.

PCR products were incubated with $\mathrm{PmaCI}$ restriction endonuclease and digestion was performed for $3 \mathrm{~h}$ at $37^{\circ} \mathrm{C}$. Restriction fragment length polymorphism products were analyzed by 4\% GTG agarose gel electrophoresis and then stained with ethidium bromide. The $\mathrm{C}$ allele (cysteine) produces only a 193-bp fragment, whereas the $\mathrm{R}$ allele (arginine) produces two fragments, one of $101 \mathrm{bp}$ and the other of $92 \mathrm{bp}$. Figure 1 shows the allele and genotype patterns.

The DNA markers were from Gibco BRL Products (New York, NY, USA). 


\section{Statistical analysis}

Genotype and allele frequencies were calculated as described by Emery (27). The chi-square test was applied to determine if genotype distributions were within HardyWeinberg equilibrium.

Descriptive statistics and logistic regression analysis were performed considering two allele groups: one with the presence of the $\mathrm{R}$ allele ( $\mathrm{RR}+\mathrm{CR}$ genotypes together) and the other with the absence of the $\mathrm{R}$ allele (CC genotype) in view of the low frequency of the RR genotype. The presence of morbidity interactions was evaluated and significance was calculated by the chi-square test $(\alpha=0.05)$. Statistical analysis was performed using SPSS 10.0 software.

The mean age of subjects with the presence of the $\mathrm{R}$ allele ( $\mathrm{RR}$ and $\mathrm{CR}$ genotypes together) was $80.05 \pm 5.14$ (range: 66-94 years) and the mean age of subjects with absence of the $\mathrm{R}$ allele (CC genotype) was $79.64 \pm 5.43$ (range: 69-97 years). We used $t$-test statistics to evaluate the two allele groups in relation to age.

The odds ratios (OR) and 95\% confidence interval $(95 \% \mathrm{CI})$ were calculated by logistic regression analysis considering the frequency among people with (presence) the $\mathrm{R}$ allele compared to that among people without (absence) the R allele. Morbidity, sex and age were considered to be independent variables in the model. The adjusted OR and $95 \% \mathrm{CI}$ for morbidity interactions were calculated by computing the exponential value obtained by adding the regression coefficients for variable interactions and the coefficients of the respective variable reference.

\section{Results}

The allele frequencies observed in our population were 0.788 for the $\mathrm{C}$ allele and 0.211 for the $\mathrm{R}$ allele. The observed genotype frequencies were: $\mathrm{CC}=0.608, \mathrm{CR}=$ 0.36 and $\mathrm{RR}=0.031$. Genotype distributions were within Hardy-Weinberg equilibrium (data not shown). The comparison of each allele group concerning age did not show any significant difference $(\mathrm{t}=0.73$; d.f. $=381 ; \mathrm{P}=\mathrm{ns})$.

The use of descriptive statistics and of the chi-square test showed a significant association between the following morbidities: cardiovascular disorder and depression $\left(\chi^{2}=10.11 ;\right.$ d.f. $\left.=1 ; \mathrm{P}<0.01\right)$, diabetes and neoplasia $\left(\chi^{2}=7.38\right.$; d.f. $\left.=1 ; \mathrm{P}<0.01\right)$, dementia and depression $\left(\chi^{2}=5.40\right.$; d.f. $=1$; $\mathrm{P}<0.05)$, diabetes and obesity $\left(\chi^{2}=6.67\right.$; d.f. $=1 ; \mathrm{P}<0.01)$, and hypertension and obesity $\left(\chi^{2}=7.97\right.$; d.f. $\left.=1 ; \mathrm{P}<0.01\right)$.

Table 1 shows the number and percent of
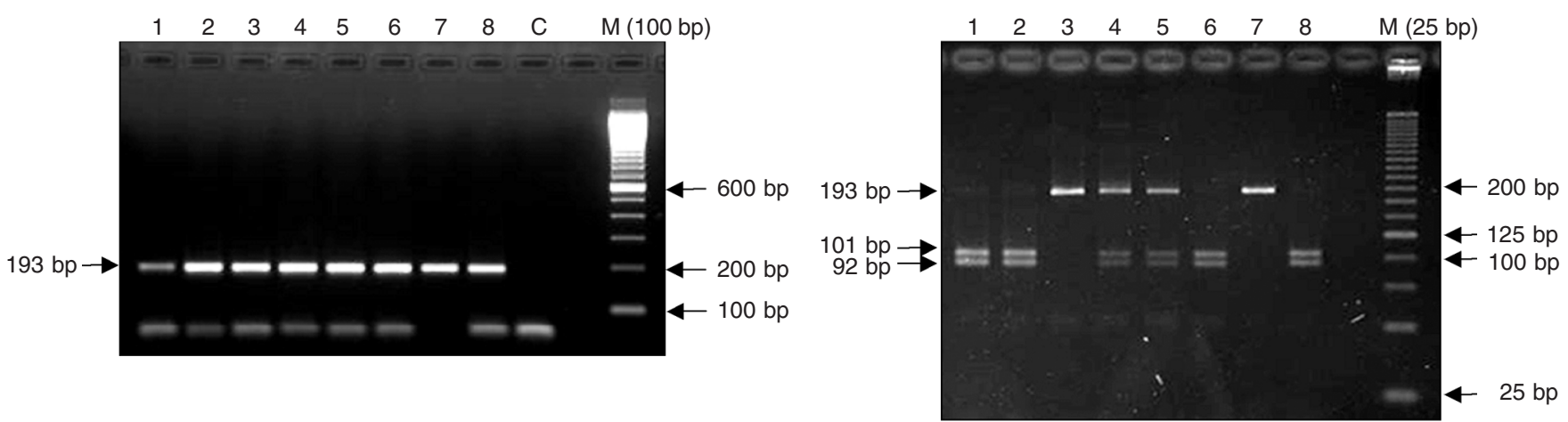

Figure 1. WRN:1367 gene polymorphism. A, PCR amplification products on $2 \%$ agarose gel. Lanes 1-8 (PCR products), C (negative control) and M (DNA marker, $100 \mathrm{bp})$. B, Restriction fragment length polymorphism on 4\% GTG agarose gel. Lanes 1, 2, 6, and 8, R allele and RR genotype ( 101 + $\sim 92 \mathrm{bp})$; lanes 3 and 7, C allele and CC genotype ( 193 bp), and lanes 4 and 5, CR genotype $(\sim 199+\sim 113+\sim 86$ bp) and M (DNA marker, 25 bp). 
Table 1. Number and percent of female and male subjects with or without each morbidity.

\begin{tabular}{lccccc}
\hline Disease & Affected female (\%) & Female (total) & Affected male (\%) & Male (total) & Total number \\
\hline Cardiovascular disease & $50(19.1)$ & 262 & $33(27.3)$ & 121 & 383 \\
Hypertension & $226(86.6)$ & 261 & $94(77.7)^{\star}$ & 121 & 382 \\
Diabetes type II & $165(63.2)$ & 261 & $77(63.6)$ & 121 & 382 \\
Dementia & $22(8.6)$ & 257 & $8(6.7)$ & 119 & 376 \\
Depression & $54(22.7)$ & 238 & $17(14.7)$ & 116 & 354 \\
Obesity & $97(45.9)$ & 211 & $30(30.9)^{\star}$ & 97 & 308 \\
Neoplasia & $24(9.3)$ & 258 & $17(14.2)$ & 120 & 378 \\
\hline
\end{tabular}

${ }^{*} \mathrm{P}<0.05$ compared to the number of affected females (chi-square test).

Table 2. Number of subjects with the presence or absence of the $\mathrm{R}$ allele in relation to sex, age and morbidity and results of logistic regression analysis.

\begin{tabular}{|c|c|c|c|c|c|c|c|c|}
\hline \multirow[t]{2}{*}{ Variables } & \multicolumn{2}{|c|}{$\begin{array}{c}\text { Presence of } \\
\mathrm{R} \text { allele }\end{array}$} & \multicolumn{2}{|c|}{$\begin{array}{l}\text { Absence of } \\
R \text { allele }\end{array}$} & \multirow[t]{2}{*}{$\begin{array}{l}\text { No. of } \\
\text { valid cases }\end{array}$} & \multicolumn{3}{|c|}{$\begin{array}{c}\mathrm{OR} \text { and } 95 \% \mathrm{Cl} \\
\text { (presence/absence of } \mathrm{R} \text { allele) }\end{array}$} \\
\hline & No. & Total & No. & Total & & OR & Lower & Upper \\
\hline Sex (female/male) & $103 / 47$ & 150 & $159 / 74$ & 233 & 383 & 0.958 & 0.565 & 1.624 \\
\hline Age $($ mean $\pm S D)$ & \multicolumn{2}{|c|}{$80.05 \pm 5.14$} & \multicolumn{2}{|c|}{$79.64 \pm 5.43$} & 383 & 0.998 & 0.952 & 1.047 \\
\hline Cardiovascular disease & 31 & 150 & 52 & 233 & 383 & 1.007 & 0.504 & 2.011 \\
\hline Diabetes type II & 96 & 150 & 146 & 232 & 382 & 0.633 & 0.324 & 1.238 \\
\hline Hypertension & 125 & 150 & 195 & 232 & 382 & 0.627 & 0.284 & 1.384 \\
\hline Obesity & 54 & 119 & 73 & 189 & 382 & 0.567 & 0.096 & 3.340 \\
\hline Depression & 29 & 149 & 42 & 216 & 354 & 1.047 & 0.460 & 2.383 \\
\hline Dementia & 12 & 149 & 18 & 227 & 376 & 1.114 & 0.334 & 3.723 \\
\hline Neoplasia & 16 & 149 & 25 & 229 & 378 & 0.527 & 0.050 & 5.598 \\
\hline
\end{tabular}

$\mathrm{OR}=$ odds ratio $; 95 \% \mathrm{Cl}=95 \%$ confidence interval; $\mathrm{SD}=$ standard deviation .

subjects of each gender in relation to morbidity. We observed a significant association between female gender and hyperten$\operatorname{sion}\left(\chi^{2}=4.85 ;\right.$ d.f. $\left.=1 ; \mathrm{P}<0.05\right)$ as well as obesity $\left(\chi^{2}=6.21\right.$; d.f. $\left.=1 ; \mathrm{P}<0.05\right)$.

Table 2 shows the number of subjects with and without the $\mathrm{R}$ allele in relation to sex, age and morbidity as well as the logistic regression results. We did not find any significant association between $W R N$ polymorphism and morbidity, sex or age. The adjusted OR and $95 \%$ CI for morbidity interactions were: 0.78 and $0.31-1.97$ for cardiovascular disease and depression, 0.70 and 0.26-1.85 for diabetes and neoplasia, 1.03 and 0.27-3.95 for dementia and depression, 0.40 and $0.12-1.35$ for hypertension and obe- sity, and 0.99 and $0.22-4.43$ for diabetes and obesity, respectively. These results did not indicate any significant association between the polymorphism and morbidity.

\section{Discussion}

In the present study, we investigated the $W R N: 1367$ allele and genotype frequencies as well as their association with major morbidities affecting elderly people in a Brazilian population sample ranging from 66 to 97 years of age.

Genotype distributions were within Hardy-Weinberg equilibrium and did not show any significant age-related effect sufficient to alter gene frequency. 
Our elderly population showed allele frequencies similar to those of populations of European origin and different from those of Japanese samples $(11,12)$. In a Finnish population, the $\mathrm{R}$ allele frequency did not differ between newborns and centenarians, indicating the absence of a protective age-related effect of this allele. The allele frequencies also did not differ among North American adults, Mexican newborns and Finnish newborns and centenarians $(3,4)$.

Some of the diseases of the subjects showed gender association, such as obesity and hypertension in women (Table 1). These findings agree with those observed among all residents over 60 in Bambuí, a community in Minas Gerais State (28). Another epidemiological investigation conducted in the Northeast and Southeast regions of Brazil also showed a higher prevalence of obesity and hypertension among women over 50 years (29).

The comparison between the number of subjects with $\mathrm{R}$ allele with those without $\mathrm{R}$ allele in relation to each morbidity (Table 2) did not differ significantly as determined by the chi-square test (data not shown).

Logistic regression analysis did not show a significant association of the polymorphism with morbidity, sex, age, or morbidity interactions. The absence of association of this polymorphism with cardiovascular diseases in our Brazilian cohort study confirmed findings observed in samples with similar allele frequencies and differed significantly from findings obtained for Japanese samples.

The occurrence of co-morbidities in elderly people is common. In our population sample we also observed an association of depression with cardiovascular disease, of type II diabetes with neoplasia and with obesity and of depression with dementia. Major depression is known to be related to higher cardiovascular mortality as confirmed in a prospective cohort study of elderly Dutch men and women and in a study of 12,866 men recruited from the Multiple Risk Factor Intervention Trial Study $(30,31)$. The association of type II diabetes with pancreatic carcinoma and breast cancer as well as obesity has been reported (32-34). There are also reports in the literature on the association between depression and dementia (35).

Codon WRN:1367 polymorphism did not show a significant association with non-insulin-dependent diabetes, as had been reported for a Japanese sample (11).

Investigating $W R N$ polymorphism and haplotype frequencies in different ethnic groups certainly strengthens the power of association and predisposition studies on agerelated morbidities since distinct populations exhibit different and specific gene frequencies $(4,36)$.

In addition, the functional significance of Cys/Arg WRN gene polymorphism in agerelated disorders is unknown. It is assumed that the R allele may confer improved WRN protein function in the nuclear localization signal, stability or catalytic activity interaction (7). We are just beginning to understand the molecular basis of the contribution of this polymorphism to protein function and its role in the aging process and pathogenesis of age-related diseases.

Our findings, however, do not eliminate the possibility of $W R N$ gene or other polymorphisms and haplotypes playing a role in the etiopathogenesis of these morbidities.

\section{References}

1. Martin GM (1978). Genetic syndromes in man with potential relevance to the pathobiology of aging. Birth Defects Original Article Series, 14: 5-39.

2. Epstein CJ, Martin GM, Schultz AL et al. (1966). Werner's syn- drome: a review of its symptomatology, natural history, pathologic features, genetics and relationship to the natural aging process. Medicine, 45: 177-221.

3. Castro E, Ogburn CE, Hunt KE et al. (1999). Polymorphisms at the 
Werner locus: I. Newly identified polymorphisms, ethnic variability of 1367 Cys/Arg and its stability in a population of Finnish centenarians. American Journal of Medical Genetics, 82: 399-403.

4. Castro E, Edland SD, Lee L et al. (2000). Polymorphisms at the Werner locus: II. 1074 Leu/Phe. 1367 Cys/Arg, longevity and atherosclerosis. American Journal of Medical Genetics, 95: 374-380.

5. Oshima J, Martin GM, Gray MD et al. (2001). Gene action at the Werner helicase locus: its role in the pathobiology of aging. In: Gilchrest BA \& Borh VA (Editors), Advances in Cell Aging and Gerontology: The Role of DNA Damage and Repair in Cell Aging. Elsevier, Amsterdam, The Netherlands.

6. Yu CE, Oshima J, Fu YH et al. (1996). Positional cloning of the Werner's syndrome gene. Science, 272: 258-262.

7. Chen L \& Oshima J (2002). Werner syndrome. Journal of Biomedicine and Biotechnology, 2: 46-54.

8. Chen L, Huang S, Lee L et al. (2003). WRN, the protein deficient in Werner syndrome, plays a critical structural role in optimizing DNA repair. Aging Cell, 2: 191-199.

9. Brosh Jr RM \& Bohr VA (2002). Roles of the Werner syndrome protein in pathways required for maintenance of genome stability. Experimental Gerontology, 37: 491-506.

10. Hickson ID (2003). RecQ helicases: caretakers of the genome. Nature Reviews. Cancer, 3: 169-178.

11. Ye L, Miki T, Nakura J et al. (1997). Association of a polymorphic variant of the Werner helicase gene with myocardial infarction in a Japanese population. American Journal of Medical Genetics, 68: 494-498.

12. Morita H, Kurihara H, Sugiyama T et al. (1999). A polymorphic variant $\mathrm{C} 1367 \mathrm{R}$ of the Werner helicase gene and atherosclerotic diseases in the Japanese population. Thrombosis and Haemostasis, 82: 160-161.

13. Ogata N, Shiraki M, Hosoi T et al. (2001). A polymorphic variant at the Werner helicase (WRN) gene is associated with bone density, but not spondylosis, in postmenopausal women. Journal of Bone and Mineral Metabolism, 19: 296-301.

14. Yamada H, Yamada Y, Fukatsu A et al. (2000). Polymorphism of Werner helicase associated gene in long-term hemodialysis patients. Nephron, 86: 543 (Letter).

15. Ramos LR, Toniolo NJ, Cendoroglo MS et al. (1998). Two-year follow-up study of elderly residents in S. Paulo, Brazil: methodology and preliminary results. Revista de Saúde Pública, 32: 397-407.

16. Whitworth JA \& World Health Organization, International Society of Hypertension Writing Group (2003). 2003 World Health Organization (WHO)/International Society of Hypertension (ISH) statement on management of hypertension. Journal of Hypertension, 21: 19831992.

17. Chobanian AV, Bakris GL, Black HR et al. (2004). Seventh Report of the Joint National Committee on Prevention, Detection, Evaluation, and Treatment of High Blood Pressure. Hypertension, 42: 12061252.

18. Anonymous (1999). Is fasting glucose sufficient to define diabetes? Epidemiological data from 20 European studies. The DECODEstudy group. European Diabetes Epidemiology Group. Diabetes Epidemiology: Collaborative Analysis of Diagnostic Criteria in Europe. Diabetologia, 42: 647-654.

19. Kyle UG, Genton L, Hans D et al. (2001). Total body mass, fat mass, fat-free mass, and skeletal muscle in older people: cross-sectional differences in 60-year-old persons. Journal of the American Geriatric Society, 49: 1633-1640.

20. Rolland-Cachera MF, Cole TJ, Sempe M et al. (1991). Body mass index variations: centiles from birth to 87 years. European Journal of Clinical Nutrition, 45: 13-21.

21. Folstein MF, Folstein SE \& McHugh PR (1975). "Mini-mental state". A practical method for grading the cognitive state of patients for the clinician. Journal of Psychiatric Research, 12: 189-198.

22. Bertolucci PH, Brucki SD, Campacci SR et al. (1994). The MiniMental State Examination in a general population: impact of educational status. Arquivos de Neuropsiquiatria, 52: 1-7.

23. Bertolucci PH, Okamoto IH, Brucki SM et al. (2001). Applicability of the CERAD neuropsychological battery to Brazilian elderly. Arquivos de Neuropsiquiatria, 59: 532-536.

24. Blay SL, Ramos LR \& Mari J de J (1988). Validity of a Brazilian version of the Older American's Resources and Services (OARS) Mental Health Screening Questionnaire. Journal of the American Geriatric Society, 36: 687-692.

25. Bush TL, Miller SR, Golden AL et al. (1989). Self-report and medical record report agreement of selected medical conditions in the elderly. American Journal of Public Health, 79: 1554-1556.

26. Lahiri DK \& Nurnberger Jr JI (1991). A rapid non-enzymatic method for the preparation of HMW DNA from blood for RFLP studies. Nucleic Acids Research, 19: 5444.

27. Emery AEH (1986). Methodology in Medical Genetics - An Introduction to Statistical Methods. 2nd edn. Longman Group, Edinburgh, UK.

28. Barreto SM, Passos VM, Cardoso AR et al. (2003). Quantifying the risk of coronary artery disease in a community: the Bambuí Project. Arquivos Brasileiros de Cardiologia, 8: 556-561.

29. Abrantes MM, Lamounier JA \& Colosino EA (2003). Overweight and obesity prevalence in Northeast and Southeast regions of Brazil. Revista da Associação Médica Brasileira, 49: 163-166.

30. Giltay EJ, Geleijnse JM, Zitman FG et al. (2004). Dispositional optimism and all-cause and cardiovascular mortality in a propective cohort of elderly Dutch men and women. Archives of General Psychiatry, 61: 1126-1135.

31. Gump BB, Matthews KA, Eberly LE et al. (2005). Depressive symptoms and mortality in men: results from the Multiple Risk Factor Intervention Trial. Stroke, 36: 98-102.

32. Krechler T, Novotny J, Zeman M et al. (2004). Pancreatic carcinoma and diabetes mellitus. Casopis Lekaru Ceskych, 143: 97-100 (Abstract).

33. Rose DP, Komninou D \& Stephenson GD (2004). Obesity, adipocytokines, and insulin resistance in breast cancer. Obesity Reviews, 5: 153-165.

34. Combe H, Vol S, Thevenot A et al. (2004). Comparison of men with impaired fasting glycaemia to controls and to diabetic subjects with fasting glycaemia from 7.0 to $7.7 \mathrm{mmol} / \mathrm{l}$ : clinical, nutritional and biological status. Diabetes and Metabolism, 30: 167-174.

35. Modrego PJ \& Ferrandez J (2004). Depression in patients with mild cognitive impairment increases the risk of developing dementia of Alzheimer type: a prospective cohort study. Archives of Neurology, 61: 1290-1293.

36. Trikka D, Fang Z, Renwick A et al. (2002). Complex SNP-based haplotypes in three human helicases: implications for cancer association studies. Genome Research, 12: 627-639. 